\title{
Van-e összefüggés az epikardiális zsírszövet és a koszorúér-betegség között?
}

\author{
Drobni Zsófia Dóra', Kolossváry Márton', Karády Júlia', Jermendy Ádám', \\ Littvay Levente², Tárnoki Ádám Domonkos³, Tárnoki Dávid László3, \\ Voros Szilard ${ }^{4}$, Jermendy György ${ }^{5}$, Merkely Béla', Maurovich-Horvat Pál ${ }^{1}$
}

${ }^{1}$ MTA-SE Lendület Kardiovaszkuláris Képalkotó Kutatócsoport, Semmelweis Egyetem, Városmajori Szív- és Érgyógyászati Klinika, Budapest; ${ }^{2}$ Közép-Európai Egyetem, Budapest; ${ }^{3}$ Semmelweis Egyetem, Radiológiai Klinika, Budapest; ${ }^{4}$ Global Genomics Group; Atlanta, GA, USA; ${ }^{5}$ Bajcsy-Zsilinszky Kórház, Budapest

Levelezési cím: Dr. Maurovich-Horvat Pál, PhD, MPH, 1122 Budapest, Városmajor utca 68., E-mail: p.maurovich-horvat@cirg.hu

A zsírszöveti kompartmenteknek szerepe lehet az ateroszklerózis kialakulásában. Korábbi adatok az abdominalis zsírszövet és a fokozott kardiovaszkuláris kockázat közötti összefüggést már igazolták, napjainkban vizsgálat tárgyát képezi az epikardiális zsírszövet (EAT) szerepe is. Egyre több adat utal arra, hogy az EAT megnövekedett mennyisége a koronáriabetegség (CAD) kockázatát növeli. Jelenlegi vizsgálatunk során arra kerestünk választ, hogy igazolható-e összefüggés az EAT térfogata és a CAD jelenléte között felnőtt, korábban kardiális eseményt nem szenvedett egyének körében.

A vizsgálatot a BUDAPEST-GLOBAL-tanulmány keretei között végeztük. Összesen 195 beteg (életkor: 56,1 $1 \pm 9,4$ év; nők $64,1 \%)$ adatait elemeztük. Minden résztvevőről kontrasztanyag nélküli CT-felvétel készült a mellkasi és felhasi régióban az EAT és az abdominalis zsírszövet mennyiségének méréséhez. A CAD jelenlétét vagy hiányát koronária-CT-angiográfia lelete alapján állapítottuk meg és a betegeket koronáriabetegségben nem szenvedők (CAD-negatív; n=89) és koronáriabetegségben szenvedők (CAD-pozitív; $n=106)$ csoportba soroltuk.

A CAD-pozitív csoport életkora, haskörfogata, EAT- és abdominalis zsírszövetértéke számottevően nagyobb volt, mint a CAD-negatív csoporté. A CAD-pozitív csoportban értékelhetően kisebb arányban voltak a nők, az elözményi adatok között gyakrabban szerepelt hipertónia, dyslipidaemia és diabétesz. A CAD-pozitív csoport szérum trigliceridértéke értékelhetően nagyobb volt, mint a CAD-negatív csoporté, a többi lipid- és vércukorértéket tekintve a két csoport között számottevő különbség nem mutatkozott. Az életkor (esélyhányados: 1,1; $p<0,001$ ), a hipertónia (esélyhányados 3,3; $p<0,05$ ), a női nem (esélyhányados 0,$1 ; p<0,001$ ) és az EAT $10 \mathrm{~cm}^{3}$-nyi értéke (esélyhányados 1,3; $p=0,001$ ) a CAD független prediktorainak bizonyult. Az EAT mennyiségének $10 \mathrm{~cm}^{3}$-rel való növekedése a CAD kockázatát 30\%-kal megnövelte. A női nem protektív tényezőnek adódott, következésképpen a férfinem pozitív prediktív tényezőnek minősült.

Az EAT mennyisége összefüggésben áll a CAD jelenlétével, ezért érdemes megfontolni értékének szerepeltetését a kardiovaszkuláris kockázatbecslő rendszerekben, a pontosság növelése érdekében.

Kulcsszavak: ateroszklerózis, kardiovaszkuláris kockázat, koszorúér-betegség, epikardiális zsírszövet, koronária-CT-angiográfia

Is there any association between epicardial adipose tissue compartment and coronary artery disease?

Various fat compartments might have an important role in the pathophysiology of atherosclerosis. Previous studies demonstrated an association between abdominal adipose tissue compartments and increased cardiovascular risk however the role of epicardial adipose tissue (EAT) is still unclear. It has been suggested that increased EAT quantity increases the risk of coronary artery disease (CAD). Our aim was to assess the relationship between the volume of EAT and the presence of CAD in subjects with negative cardiovascular medical history.

We included 195 subjects (age: $56.1 \pm 9.4$ years, female $64.1 \%$ ) from the BUDAPEST-GLOBAL study. All subjects underwent coronary CT angiography (CTA) and were classified into groups with and without CAD (CAD-positive: $n=106$ and CAD-negative: $n=89$, respectively), based on the presence or absence of any plaque in coronary CTA. We measured the EAT volume on a native cardiac scan and the abdominal adipose tissue areas on a single CT-slice acquired at the L3/L4 level.

Subjects from the CAD-positive group were older, had a larger waist circumference, EAT volume and abdominal adipose tissue areas than subjects from the CAD-negative group. There were fewer females in the CAD-positive group, and in this group the presence of hypertension, dyslipidemia and diabetes were more frequent. Considering the lipid and glucose levels, we observed a significant difference only in the serum triglyceride levels. Age (OR: $1.1 p<0.001)$, hypertension (OR: $3.3 p<0.05)$, female sex (OR: $0.1 p<0.001)$ and the volume of EAT in $10 \mathrm{~cm}^{3}$ clusters (OR: $\left.1.3 p=0.001\right)$ were independent predictors for CAD. A $10 \mathrm{~cm}^{3}$ increment in the volume of EAT increases the risk of CAD with $30 \%$. Female sex was a protective factor therefore male sex is a positive predictive factor.

Since EAT shows a significant association with the presence of CAD, it is reasonable to consider the quantity of EAT in risk assessments to improve the accuracy of CAD risk prediction.

Keywords: atherosclerosis, cardiovascular risk, coronary artery disease, epicardial adipose tissue, coronary CT-angiography 
A szív- és érrendszeri megbetegedések világszerte vezetik a morbiditási és mortalitási statisztikákat, jelentős terhet róva az egészségügyi ellátórendszerre és a gazdaságra. Ezek a megbetegedések 2012-ben az Európai Unió 28 országában összesen 1,9 millió haláleset hátterében álltak, ez az összes haláleset 37,9\%-át jelenti. Magyarországon a szív- és érrendszeri megbetegedések közel kétszer-háromszor annyi halálért tehetők felelőssé, mint az Európai Unió más országaiban. Magyarország a halálozási számával 2012-ben a negyedik helyen állt az Európai Unión belül (1). A szív- és érrendszeri betegségek által okozott népegészségügyi terhek egyre nőnek, ezért kiemelt fontosságú a személyre szabott prevenciós és terápiás eljárások fejlesztése. Ennek során a kutatásoknak leginkább a betegség mechanizmusának egyre pontosabb felderítésére és a primer prevenció minél szélesebb körü megerősítésére érdemes fókuszálni.

A koszorúér-betegség (CAD) előre történő becslése nagyban segítheti a prevenciós törekvéseket. A jelenleg használt kockázatbecslő rendszerek a kardiovaszkuláris halálozások egyharmadát nem képesek azonosítani, jellemző módon túlértékelik a kis kockázattal és alulértékelik a nagy kockázattal rendelkező betegeket (2). Ebből adódóan a kockázatbecslés pontosítása, a patomechanizmusban potenciálisan szerepet kapó új tényezőknek a kockázatbecslő rendszerbe történő bevonása komoly klinikai jelentőséggel bír.

Munkacsoportunk célja olyan képi markerek azonosítása, amelyek a jelenleg alkalmazott kockázatbecslő rendszerekbe könnyedén beilleszthetők, elősegítve azok pontosabb alkalmazását. Ezen a téren a nagy kockázatú koszorúér-plakkokra jellemző morfológiának, a különböző plakkeloszláson alapuló pontrendszernek, vagy minden további, viszonylag könnyen mérhető paraméternek nagy jelentősége lehet. A klinikai kutatásunk egyik irányát a zsírszöveti kompartmentek és a CAD közötti összefüggés tanulmányozása képezi. Korábbi adatok az abdominalis zsírszövet és a fokozott kardiovaszkuláris kockázat közötti összefüggést már igazolták $(3,4,5)$, napjainkban a figyelem középpontjába az epikardiális zsírszövet (EAT) került.

Az EAT a myocardium és a visceralis pericardium között található. A szív $80 \%$-át takarja és átlagosan a szív súlyának 20\%-át teszi ki. Fejlődéstanilag a splanchnicus mesodermából származik, vérellátását a koszorúerek biztosítják (6). Élettani funkciói között a hypothermia és a mechanikus sérülések elleni védelmet jelölik meg, de az EAT fontos szerepet kap a szívizomzat energia-ellátásában is. Mennyisége nő az életkor előrehaladtával és a testsúly növekedésével, férfiak EAT-értéke nagyobb, mint azonos korú nőké. Mennyisége megnő 2-es típusú diabéteszben, prediabéteszben és metabolikus szindrómában. Az EAT jelentős mennyiségben termel különböző citokineket és hormonokat, amelyek paracrin és vasocrin úton befolyásolhatják a koszorúér-plakkok képződését. Egyre több adat utal arra, hogy az EAT megnövekedett mennyisége a CAD kockázatát növeli $(7,8,9,10)$.

Jelenlegi vizsgálatunk során arra kerestünk választ, hogy igazolható-e összefüggés az EAT térfogata és a CAD jelenléte között felnőtt, korábban kardiális eseményt nem szenvedett egyének körében. Az EAT mennyiségét és a CAD jelenlétét/hiányát CT-vizsgálattal ítéltük meg.

\section{Vizsgált egyének és módszerek}

A vizsgálatot a BUDAPEST-GLOBAL (Burden of Atherosclerotic Plaques Study in Twins - Genetic Loci and the Burden of Atherosclerotic Lesions) tanulmány keretei között végeztük. A vizsgálat célját és tervét, a módszertant, a beválasztási és kizárási kritériumokat külön közleményben publikáltuk (11). Röviden: A vizsgálatban egy- és kétpetéjü, de azonos nemü felnőtt (életkor >18 év) ikeregyének vettek részt, az alapvizsgálat eredeti célkitűzésének megfelelően. A betegek beválasztásában a Magyar Ikerregiszter adatbázisa volt segítségünkre (12). A bevont egyének kórelőzményi adatai között átvészelt kardiovaszkuláris esemény nem szerepelt. A vizsgálatot etikai engedély (ETT TUKEB 58401/2012/EKU [828/PI/12], Amendment-1: 12292/2013/EKU [165/2013]) birtokában végeztük, valamennyi beteg - kellő felvilágosítást követően - írásbeli beleegyezését adta a vizsgálathoz. A jelen tanulmányban összesen 195 beteg adatait elemeztük. A betegeket a koronária-CT-angiográfia (koronária-CTA; Id. később) lelete alapján koronáriabetegségben nem szenvedők (koronáriabetegség negatív; CAD-negatív; $n=89$ ) és koronáriabetegségben szenvedő (koronáriabetegség pozitív; CAD-pozitív; n=106) csoportba soroltuk. A beteget fontosabb klinikai és laboratóriumi adatait az 1. táblázat tartalmazza. A két csoportba való besorolás szigorú kritériumok szerint történt, mivel azokat az egyéneket is a CAD-pozitív csoportba soroltuk, akiknél csupán egyetlen, akár minimális fokú koronária-szükületet okozó plakk volt azonosítható.

Minden résztvevőről kontrasztanyag nélküli, szük látómezejü, prospektív EKG-kapuzott, axiális CT-felvétel készült a mellkasi és felhasi régióban 256-szeletes CT-készülékkel (Brilliance iCT; Philips HealthTech, Best,

\section{Rövidítések:}

CAD: coronary artery disease (koronáriabetegség); CT: computed tomography (komputertomográfia); CTA: CT angiography (CT-angiográfia); EAT: epicardial adipose tissue (epikardiális zsírszövet); HU: Hounsfield unit (Hounsfield egység); MRI: magnetic resonance imaging (mágneses rezonancia képalkotó vizsgálat); SAT: subcutaneous adipose tissue (subcutan zsírszövet); VAT: visceral adipose tissue (visceralis zsírszövet) 
1. TÁBLÁZAT. A vizsgált egyének klinikai-laboratóriumi adatai és a zsírszöveti kompartmentek alakulása

\begin{tabular}{|c|c|c|c|}
\hline & $\begin{array}{c}\text { Koszorú- } \\
\text { ér-betegség } \\
\text { negatív cso- } \\
\text { port (n=89) } \\
\text { (átlag } \pm \text { SD) }\end{array}$ & $\begin{array}{l}\text { Koszorú- } \\
\text { ér-betegség } \\
\text { pozitív cso- } \\
\text { port }(n=106) \\
\text { (átlag } \pm \text { SD) }\end{array}$ & $\mathbf{p}$ \\
\hline Életkor (év) & $51,9 \pm 9,3$ & $59,7 \pm 8,0$ & $<0,001$ \\
\hline Női nem & $70(78,6 \%)$ & $55(51,9 \%)$ & $<0,001$ \\
\hline $\begin{array}{l}\text { Magasvérnyomás- } \\
\text { betegség }\end{array}$ & $20(22,5 \%)$ & $62(58,5 \%)$ & $<0,001$ \\
\hline Dyslipidaemia & $30(33,7 \%)$ & $55(51,9 \%)$ & 0,014 \\
\hline Diabetes mellitus & $4(4,5 \%)$ & $14(13,2 \%)$ & 0,046 \\
\hline Haskörfogat (cm) & $92,8 \pm 11,2$ & $100,4 \pm 14,9$ & $<0,001$ \\
\hline $\operatorname{EAT}\left(\mathrm{cm}^{3}\right)$ & $73,9 \pm 27,3$ & $117,2 \pm 46,8$ & $<0,001$ \\
\hline SAT $\left(\mathrm{cm}^{2}\right)$ & $202,0 \pm 83,5$ & $230,3 \pm 102,6$ & $<0,001$ \\
\hline VAT $\left(\mathrm{cm}^{2}\right)$ & $115,5 \pm 60,1$ & $190,7 \pm 89,9$ & $<0,001$ \\
\hline $\begin{array}{l}\text { Összkoleszterin } \\
(\mathrm{mmol} / \mathrm{l})\end{array}$ & $5,6 \pm 1,0$ & $5,5 \pm 1,1$ & 0,598 \\
\hline Triglicerid $(\mathrm{mmol} / \mathrm{l})$ & $1,3 \pm 0,9$ & $1,7 \pm 1,1$ & 0,021 \\
\hline $\begin{array}{l}\text { LDL-koleszterin } \\
(\mathrm{mmol} / \mathrm{l})\end{array}$ & $3,5 \pm 1,0$ & $3,5 \pm 1,0$ & 0,847 \\
\hline $\begin{array}{l}\text { HDL-koleszterin } \\
(\mathrm{mmol} / \mathrm{l})\end{array}$ & $1,7 \pm 0,3$ & $1,6 \pm 0,4$ & 0,070 \\
\hline $\begin{array}{l}\text { Éhomi vércukor } \\
(\mathrm{mmol} / \mathrm{l})\end{array}$ & $5,2 \pm 0,9$ & $5,5 \pm 1,6$ & 0,056 \\
\hline
\end{tabular}

EAT: epikardiális zsírszövet; SAT: subcutan zsírszövet; VAT: visceralis zsírszövet

The Netherlands). A natív felvételeket használva határoztuk meg az EAT mennyiségét. A lumbális III-IV. csigolya magasságában elkészített vékony hasi CT-szelet alapján mértük az abdominalis subcutan és visceralis zsírszövet (SAT és VAT) mennyiségét, a módszerrel már korábbi tapasztalatok is rendelkezésre álltak (13). Ezt követően történt a koronária-CTA, amelynek segítségével azonosítottuk a CAD jelenlétét vagy hiányát. Az EAT kvantifikálásához a natív felvételeken szeletenként jelöltük ki a pericardiumot a pulmonalis fötörzs oszlásától a rekeszizom szintjéig. Az EAT mennyiségét ( $\mathrm{cm}^{3}$-ben megadva) számítógépes szoftver (Extended Brilliance Workspace; Philips Healthcare) segítségével összesítettük a pericardium visceralis lemeze és a szívizom között. A hasi szeleteken ugyanezt a szoftvert használva ( $\mathrm{cm}^{2}$-ben megadva) számítottuk ki a SAT és a VAT mennyiségét (1. ábra). A szoftver felismerte a hasizomzatot (bizonytalanság esetén manuális korrekcióra nyílt lehetőség), amely a SAT és a VAT határaként szerepelt. Zsírszövetként azonosítottuk a -45 és -195 HU közötti denzitást. A koronária-CTA elkészítésének technikai részleteit a módszertani közlemény tartalmazza (12). A felvételeket egyenként értékeltük ki, a betegeket koronária-plakkal rendelkező (CAD-pozitív) és nem rendelkező (CAD-negatív) csoportba soroltuk. A betegek antropometriai paramétereit (testsúly, test- magasság, haskörfogat) és vérnyomását a vizsgálat előtt mértük meg. Az előzményi adatokat, az életmódbeli sajátosságokat kérdőív segítségével tisztáztuk. A laboratóriumi adatok meghatározásához éhomi vénás vérmintát használtunk, a vérvétel a vizsgálat előtt történt.

A statisztikai analízist SPSS és Mplus programmal végeztük. A két csoport összehasonlítására Student féle 2-mintás t-próbát használtunk. Csoportokra korrigált robosztus maximum likelihood becslés segítségével javítottuk az ikreknél felmerülő esetek függetlenségének hiányát. A CAD és a kockázati tényezők (beleértve az EAT-, SAT- és VAT-értékeket is) összefüggésének megítélésére logisztikus regressziót végeztünk, amelynek során a modellben az alábbi adatokat használtuk: női nem, életkor, magasvérnyomás-betegség, dyslipidaemia, diabetes mellitus, EAT (10 $\mathrm{cm}^{3}$ mennyisége), SAT, VAT. Az adatokat átlag $\pm S D$ formában közöljük. A $p<0,05$ értéket tekintettük szignifikánsnak.

\section{Eredmények}

A CAD-pozitív csoport életkora, haskörfogata, EAT-, SAT- és VAT-értéke számottevően nagyobb volt, mint a CAD-negatív csoporté. A CAD-pozitív csoportban értékelhetően kisebb arányban voltak a nők, az előzményi adatok között gyakrabban szerepelt hipertónia, dyslipidaemia és diabétesz. A CAD-pozitív csoport szérum trigliceridértéke értékelhetően nagyobb volt, mint a
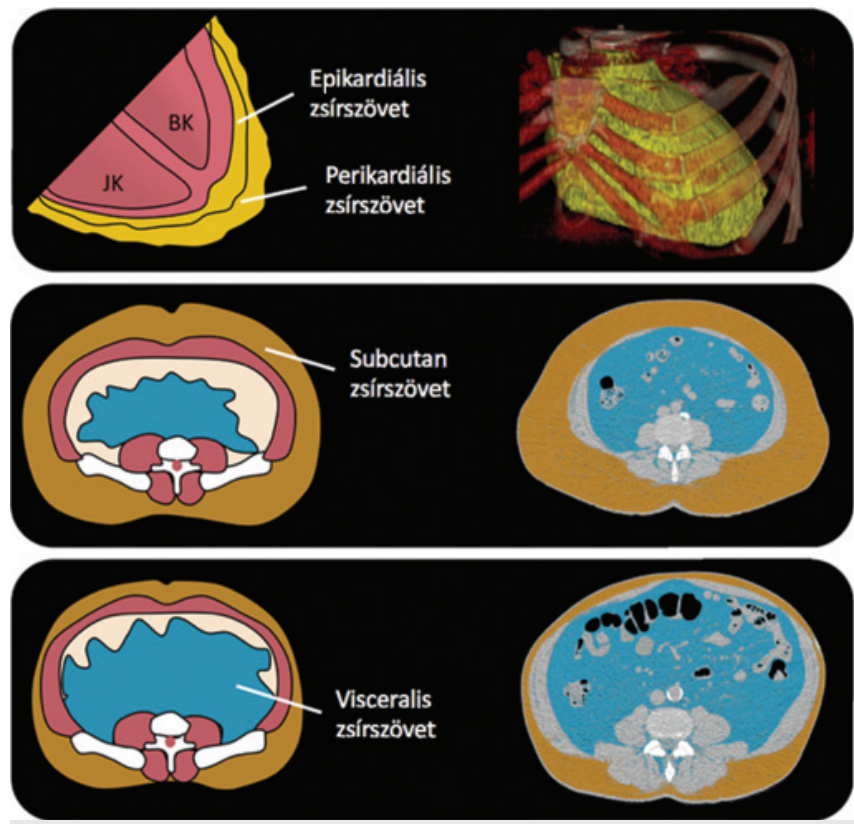

1. ÁBRA. A vizsgált zsírszöveti raktárak sematikus ábrázolása (baloldal) és CT-képe (jobb oldal). FELÜL: epikardiális zsírszövet (EAT). KÖZÉPEN: domináló abdominalis subcutan zsírszövet (SAT). ALUL: domináló abdominalis visceralis zsírszövet (VAT) 
2. TÁBLÁZAT. A koszorúér-betegség összefüggése a klinikai/ laboratóriumi és a zsírszöveti paraméterekkel (logisztikus regresszió)

\begin{tabular}{|l|c|c|}
\hline & Esélyhányados & p \\
\hline Életkor & 1,1 & $<0,001$ \\
\hline Női nem & 0,1 & $<0,001$ \\
\hline Magasvérnyomás-betegség & 3,3 & 0,029 \\
\hline Dyslipidaemia & 1,8 & 0,208 \\
\hline Diabetes mellitus & 1,5 & 0,638 \\
\hline EAT $\left(10 \mathrm{~cm}^{3}\right)$ & 1,3 & 0,001 \\
\hline SAT $\left(\mathrm{cm}^{2}\right)$ & 1,0 & 0,057 \\
\hline VAT $\left(\mathrm{cm}^{2}\right)$ & 1,0 & 0,803 \\
\hline
\end{tabular}

EAT: epikardiális zsírszövet; SAT: subcutan zsírszövet; VAT: visceralis zsírszövet

CAD-negatív csoporté, a többi lipid- és vércukorértéket tekintve a két csoport között számottevő különbség nem mutatkozott (1. táblázat).

A logisztikus regresszió során az életkor (esélyhányados: 1,$1 ; p<0,001$ ), a hipertónia (esélyhányados 3,3; $p<0,05$ ), a női nem (esélyhányados 0,$1 ; p<0,001$ ) és az EAT $10 \mathrm{~cm}^{3}$-nyi értéke (esélyhányados 1,3; $p=0,001$ ) a CAD független prediktorainak bizonyultak. Az EAT mennyiségének $10 \mathrm{~cm}^{3}$-rel való növekedése a CAD kockázatát $30 \%$-kal megnövelte. A női nem protektív tényezőnek adódott, következésképpen a férfinem pozitív prediktív tényezőnek minősült (2. táblázat).

\section{Megbeszélés}

Vizsgálatunk eredménye szerint az EAT mennyisége más tényezők (életkor, hipertónia, férfinem) mellett öszszefüggésben áll a CAD jelenlétével. Az EAT mennyiségének $10 \mathrm{~cm}^{3}$-rel való növekedése a CAD kockázatát $30 \%$-kal megnöveli. Ez alapján érdemes megfontolni az EAT-értékének szerepeltetését a kardiovaszkuláris kockázatbecslő rendszerekben, a pontosság növelése érdekében.

Az EAT térfogatát kontrasztanyag nélküli, natív CT-felvételen mértük. A módszer viszonylag könnyen kivitelezhető, kevésbé időigényes, az EAT körvonalai jól azonosíthatók, az eredmény megbízható, a sugárterhelés minimális (10). Az EAT mérésére más módszerek is rendelkezésre állnak.

A transthoracalis echokardiográfia az EAT térfogata helyett csupán vastagságának meghatározása alkalmas, költséghatékony, gyors és könnyen hozzáférhető módszer (14). A vizsgálat során parasternalis rövid és hosszú tengely nézetekben három egymást követő végszisztoléban történik a vastagság meghatározása. Az echokardiográfia nagymértékben vizsgálófüggő és a mért EAT-vastagság nem feltétlenül korrelál az EAT-térfogattal. A szívet az EAT nem egyenlő vastagságban borítja az egyes szegmentumok fölött, ezért a mérés helye befolyásolhatja a mért értéket. $A$ módszer intra- és inter-obszerver variabilitása gyenge, a mért érték esetenként szignifikánsak különbözik a CT során mért értékektől (14).

Az EAT mérhető MRI segítségével is, bár a vizsgálat drága és nehezebben hozzáférhető (15). Teljes körben elfogadott referenciamódszer nem létezik az EAT mérésére. $A$ vizsgálat során a rövid tengely felvételeken lehetőség nyílik a zsír mennyiségének számszerüsítésére, amely jól reprodukálható, a CT-mérésekhez hasonlóan. Meg kell azonban említeni, hogy a rutinszerüen végzett szív-MRI során használt szekvenciáknál nincs lehetőség a pericardium határának pontos kijelölésére, ebből adódóan az epikardiális és perikardiális zsír együttes meghatározása történik (kiegészítő protokoll alkalmazásával lehetőség nyílik az elkülönítésre, de ez többlet vizsgálati időt jelent).

Vizsgálatunk eredménye szerint az EAT mennyisége összefügg a CAD jelenlétével. Az adat arra utal, hogy az EAT-nak szerepe lehet a CAD kialakulásának patomechanizmusában. Ezt az elképzelést több adat támogatja. Az irodalmi adatok közül kiemelendő egy korai patológiai megfigyelés, amely leírta, hogy miokardiális bridge szindrómában a csak myocardium által fedett koronáriaszakasz plakkmentes volt, jelezvén azt, hogy az EAT-nak szerepe lehet a plakk-képződésben (16). Hasonlóan fontosak voltak a korai megfigyelések között Mazurek és munkatársai adatai, akik összehasonlító tanulmányukban leírták az EAT és a SAT közötti funkcionális különbségeket (17). Ezt követően általánosan elfogadottá vált, hogy az EAT inflammatorikus citokinek révén paracrin és vasocrin úton hozzájárulhat a plakk-képződéshez. Jelenlegi tanulmányunk keresztmetszeti jellegéből adódik, hogy az EAT mennyisége és a CAD jelenléte közötti összefüggés dokumentálása nem jelenti egyben az ok-okozati összefüggés megállapítását is. Ehhez prospektív jellegü vizsgálatra van szükség. Az ilyen, támogató jellegű vizsgálatok száma azonban egyelőre csekély $(18,19)$. Ugyanakkor figyelemre méltó, hogy az utóbbi időben intervenciós vizsgálatok eredményei is napvilágot láttak, amelyek igazolták, hogy életmód-terápiával, bariátriai sebészeti beavatkozással vagy gyógyszeres kezeléssel (atorvastatin, sitagliptin, exenatid, liraglutid adásával) az EAT mennyisége csökkenthető elhízott, 2-es típusú cukorbetegek körében (20).

Az eredmények értékelésekor - a keresztmetszeti jelleg mellett - további sajátosságokat is szem előtt kell tartani. A vizsgált egyének kardiológiai szempontból panaszmentesek voltak, ebből adódóan az összefüggés általánosítása, más betegcsoportokra történő alkalmazása korlátozott. A CAD-pozitív és CAD-negatív esetek CT-morfológiai elkülönítése nem esik törvényszerüen egybe a klinikai alapú megítéléssel. Csak további vizsgálattal tisztázható az, hogy az EAT figyelembe vétele növeli-e a kardiovaszkuláris kockázatbecslés pontosságát. 


\section{Következtetések}

Összefoglalva megállapítható, hogy az EAT mennyisége szoros összefüggést mutat a $C A D$ jelenlétével. Eredményünk alátámasztja azt a hipotézist, amely szerint az EAT a koszorúér-ateroszklerózis létrejöttében kóroki szerepet játszhat. Az EAT meghatározása és értékének kockázatbecslő rendszerekbe történő beépítése elősegítheti a kardiovaszkuláris kockázat pontosabb, személyre szabott becslését.

\section{Köszönetnyilvánítás}

A vizsgálat az EFSD (European Federation for the Study of Diabetes) New Horizons Programme kutatási támogatásával valósult meg.

\section{Irodalom}

1. WHO |Cardiovascular diseases (CVDs).

http://www.who.int/mediacentre/factsheets/fs317/en/

2. Grover SA, Paquet S, Levinton C, et al. Estimating the benefits of modifying risk factors of cardiovascular disease. Arch Intern Med 1998; 158(6): 655-622. Erratum: Arch Intern Med 1998; 158(11): 1228. https://doi.org/10.1001/archinte.158.6.655

3. Despres JP, Lemieux I. Abdominal obesity and metabolic syndrome. Nature 2006; 444(7121): 881-887.

https://doi.org/10.1038/nature05488

4. Balagopal PB, de Ferranti SD, Cook S, et al. Nontraditional risk factors and biomarkers for cardiovascular disease: mechanistic, research, and clinical considerations for youth: a scientific statement from the American Heart Association. Circulation 2011; 123(23): 2749-2769. https://doi.org/10.1161/CIR.0b013e31821c7c64

5. Kershaw EE, Flier JS. Adipose tissue as an endocrine organ. J Clin Endocrinol Metab 2004; 89(6): 2548-2556.

https://doi.org/10.1210/jc.2004-0395

6. Sacks HS, Fain JN. Human epicardial adipose tissue: a review. Am Heart J 2007; 153(6): 907-917.

https://doi.org/10.1016/.ahj.2007.03.019

7. lacobellis G, Malavazos AE, Corsi MM. Epicardial fat: from the biomolecular aspects to the clinical practice. Int J Biochem Cell Biol 2011; 43(12): 1651-1654.

https://doi.org/10.1016/j.biocel.2011.09.006

8. Salazar J, Luzardo E, Mejías JC, et al. Epicardial fat: physiological, pathological, and therapeutic implications. Cardiol Res Pract
2016; 2016: 1291537. doi: 10.1155/2016/1291537.

9. Kim BJ, Cheong ES, Kang JG, et al. Relationship of epicardial fat thickness and nonalcoholic fatty liver disease to coronary artery calcification: From the CAESAR study. J Clin Lipidol 2016; 10(3): 619-626. https://doi.org/10.1016/j.biocel.2011.09.006

10. Nagy E, Jermendy ÁL, Merkely B, et al. Clinical importance of epicardial adipose tissue. Arch Med Sci, epub ahead 2016. 10. 26. DOI: 10.5114/aoms.2016.63259, access: https://doi.org/10.5114, aoms. 2016.63193.

11. Maurovich-Horvat P, Tárnoki DL, Tárnoki AD, et al. Rationale, design, and methodological aspects of the BUDAPEST-GLOBAL Study (Burden of Atherosclerotic Plaques Study in Twins-Genetic Loci and the Burden of Atherosclerotic Lesions). Clin Cardiol 2015; 38(12): 699-707. https://doi.org/10.1002/clc.22482

12. Littvay L, Métneki J, Tárnoki AD, et al. The Hungarian Twin Registry. Twin Res Hum Genet 2013; 16(1): 185-189.

https://doi.org/10.1017/thg.2012.76

13. Maurovich-Horvat $P$, Massaro J, Fox CS, et al. Comparison of anthropometric, area- and volume-based assessment of abdomina subcutaneous and visceral adipose tissue volumes using multi-detector computed tomography. Int J Obes (Lond) 2007; 31(3): 500-506. https://doi.org/10.1038/sj.ijo.0803454

14. Saura D, Oliva MJ, Rodríguez D, et al. Reproducibility of echocardiographic measurements of epicardial fat thickness. Int J Cardio 2010; 141(3): 311-313. https://doi.org/10.1016/j.ijcard.2008.11.127 15. van der Meer RW, Lamb HJ, Smit JWA, et al. MR imaging evaluation of cardiovascular risk in metabolic syndrome. Radiology 2012; 264(1): 21-37. https://doi.org/10.1148/radiol.12110772

16. Ishii T, Asuwa N, Masuda S, et al. The effects of a myocardia bridge on coronary atherosclerosis and ischaemia. J Pathol 1998: 185(1): 4-9.https://doi.org/10.1002/(SICI)1096-9896(199805)185:1 17. Mazurek T, Zhang L, inflammatory mediators Zalewski A, et al Human epicardial adipose tissue is a source of. Circulation 2003; 108(20): 2460-2466.

https://doi.org/10.1161/01.CIR.0000099542.57313.C5

18. Ding J, Hsu FC, Harris TB, et al. The association of pericardial fat with incident coronary heart disease: the Multi-Ethnic Study of Atherosclerosis (MESA). Am J Clin Nutr 2009; 90(3): 499-504. https://doi.org/10.3945/ajcn.2008.27358

19. Cheng VY, Dey D, Tamarappoo B, et al. Pericardial fat burden on ECG-gated noncontrast CT in asymptomatic patients who subsequently experience adverse cardiovascular events. JACC Cardiovasc Imaging 2010; 3(4): 352-360.

https://doi.org/10.1016/j.jcmg.2009.12.013

20. lacobellis G. Epicardial fat: a new cardiovascular therapeutic target. Curr Opin Pharmacol 2016; 27: 13-8. https://doi.org/10.1016/j coph 